\title{
Promoting and Interpreting Geoheritage at the Local Level-Bottom-up Approach in the Land of Extinct Volcanoes, Sudetes, SW Poland
}

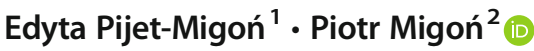

Received: 5 November 2018 / Accepted: 10 April 2019 / Published online: 26 April 2019

(C) The Author(s) 2019

\begin{abstract}
This paper reviews recent developments focused on the promotion of geoheritage in the region of Kaczawskie Mountains and Kaczawskie Foothills in the Sudetes, SW Poland. Since ancient volcanic features are of primary interest, the brand name "Land of Extinct Volcanoes" is consistently used in territorial marketing, although geoheritage values cover much wider spectrum of geology and geomorphology. The scientific understanding of Earth history was long realized by restricted academic circles only, but since the 1990s, increasing attempts to develop regional tourist product based on geoheritage have been observed. They intensified in the twentyfirst century, with the bottom-up approach evidently taking over, although close, formalized collaboration with scientists is a distinctive feature. The long-term goal of the Local Action Group is to join the UNESCO Global Geopark network and step by step the relevant criteria are being fulfilled. The case of Land of Extinct Volcanoes illustrates the crucial role of local communities and local leaders in the long-term strategy of geoheritage promotion and geotourism development.
\end{abstract}

Keywords Geotourism · Geoeducation · Geosites · Volcanic tourism · Sudetes

\section{Introduction}

Effective care about geoheritage requires, simultaneously, (i) good scientific understanding of geological past and geomorphological diversity of an area, so that the significance of geoheritage may be properly evaluated; (ii) solid legal framework of geoheritage conservation; and (iii) adequate awareness at the local level of both geoheritage itself, as well as of its potential as a catalyst of local and regional development, followed by involvement of local communities in geoheritage matters. These three pillars converge within the idea of geoparks, but the label of a UNESCO Global Geopark is not mandatory to develop these various, geoheritage-oriented activities. In fact,

This article is part of the Topical Collection on Geoheritage and Conservation: Modern Approaches and Applications Towards the 2030 Agenda, IX ProGEO Symposium, Poland, 25-28th June, 2018

Piotr Migoń

piotr.migon@uwr.edu.pl

1 Institute of Tourism, Wrocław School of Banking, Fabryczna 29-31, 53-609 Wrocław, Poland

2 Institute of Geography and Regional Development, University of Wrocław, pl. Uniwersytecki 1, 50-137 Wrocław, Poland the presence of these three pillars and achievements in each field are necessary to fulfill requirements to become a member of the UNESCO Global Geoparks family. Observations from around the world show that various failures to establish or maintain geoconservation projects, including withdrawals from the Global Geopark Network (now UNESCO Global Geoparks), resulted from either lack of support at the top level or insufficient involvement at the local level. The aim of this paper is to review achievements and experience in geoheritage promotion accomplished at the local level, in a region in south-west Poland, branded as the Land of Extinct Volcanoes. The core of geoheritage values is related to relicts of past volcanism, but the bottom-up activities are wider in scope. In this paper, we intend to show how the local awareness has been built upon results of academic research and that maintaining links between the local communities and external experts is crucial for success of geoheritageoriented activities in the longer term. Thus, the paper is on one hand a case study, but illustrates several wider issues and may be considered as a contribution to develop a code of good practice in promoting geoheritage on the other one. For simplicity, the brand name "Land of Extinct Volcanoes" will be used throughout the paper rather than local geographical names, as it is not equal to any of the geographical regions or administrative units. 


\section{Area of Interest and Its Geoscientific Understanding}

The Land of Extinct Volcanoes is an informal name used in territorial marketing, pertinent to the part of the Sudetes mountain range in south-west Poland and the adjacent part of the lowland (Chojnów Plain). The name has been chosen to unify 14 neighboring administrative units at the local level (municipalities), associated in one Local Action Group (LAG) (Fig. 1). Geographically, it corresponds to the region of Pogórze Kaczawskie (Kaczawskie Foothills, or "hilly land") and adjacent areas, typified by low relief and extensive upland surfaces, locally interrupted by residual hills, often of volcanic origin, and fluvial gorges (Fig. 1). Whereas geomorphology of the area is not very conspicuous, although not without various features of interest, it is the geological heritage sensu stricto that makes the region outstanding in Poland and possibly beyond.

The geological structure of the area integrates elements of preVariscan history such as submarine volcanism, limestone deposition, melanges, subsequent metamorphism of primary lavas, and amalgamation of terranes by the time of Variscan orogeny (Baranowski et al. 1990; Aleksandrowski and Mazur 2002), with the sedimentary record of geological evolution in the late Paleozoic, most of the Mesozoic and part of the Cenozoic (Solecki 1994, 2011; Chrzastek and Wojewoda 2011). Within the latter, deposition of gold-bearing sands and gravels in the Pliocene and early Pleistocene (Grodzicki 1972) is worth noting for its relevance to the recent developments of geotourist product. Interestingly, the region was once thought as a classic example of Caledonian structures in Central Europe, but extensive research in the 1970s and 1980s invalidated this view and provided a cornerstone to revisit the Paleozoic history of the Sudetes (Baranowski et al. 1990). From a geomorphological point of view, the region is an excellent teaching ground to examine relationships between lithology, rock strength and landforms (Placek 2011), the legacy of glaciation, and periglacial processes acting in the Pleistocene (Migoń et al. 2002; Migoń and PijetMigoń 2016). It also hosts some karst which is a largely unexplored archive of environmental change, probably since the midCenozoic (Pulina 1977; Rogala 2003).

However, the most valuable component of regional geoheritage is the legacy of three main volcanic periods, of vastly different ages, geotectonic context, and the nature of volcanic products which survived until the present day. The oldest volcanic period dates back to early Paleozoic (Cambrian-Silurian) and involved submarine effusions in an incipient rift setting, producing mainly seafloor basalts. These were subsequently changed in a low-grade metamorphic environment into greenschists which now form extensive, rather monotonous rock complexes in the Kaczawskie Foothills and the adjacent Kaczawskie Mountains. However, locally the original pillow lava structures survived and their outcrops represent unique geosites of national significance. Of minor importance were trachytic lava flows and subvolcanic intrusions (Kryza and Muszyński 1992), which now form scenic tors and crags (Kasprzak and Traczyk 2009). The second volcanic period is causally related to the waning stages of Variscan orogeny in the early Permian. Volcanism was bimodal, with rhyolites and trachybasalts as dominant rock types, and lava domes and short flows as the main resultant surface manifestations. Pyroclastic deposits are sandwiched between lava flows and sheets in certain localities (Awdankiewicz 2006). Permian volcanic rocks are generally poorly exposed, but several abandoned quarries offer good insights into the anatomy of volcanic bodies, whereas crags and cliffs add to the scenery at the local scale.

The third and most evident in terms of geomorphic expression is Cenozoic volcanism, primarily basaltic. The oldest basalts are $\mathrm{K}-\mathrm{Ar}$ dated for c. $38 \mathrm{Ma}$ and the youngest erupted c. $21 \mathrm{Ma}$ ago (Badura et al. 2005; Birkenmajer et al. 2007). Most common in the region are isolated, singular outcrops interpreted as remnants of former volcanic conduits leading to the long eroded volcanic cones, with some localities considered as plugs or probable subaerial flows (Birkenmajer 1967). More extensive lava flows occur beyond the geographical limits of Kaczawskie Foothills, further to the east, on the Chojnów Plain, but still within the informal limits of the Land of Extinct Volcanoes. Due to their quality, many basalt outcrops were quarried in the past, or they are still quarried. The former quarries expose instructive examples of columnar jointing, whereas some exposures are more complex and show various generations of lavas, contacts with country rock, and pyroclastic intercalations (Birkenmajer 1967). In several places, columnar jointing is exposed naturally, on crags and cliffs, supplying angular debris to the scree slopes below (Migoń et al. 2002; Migoń and Pijet-Migoń 2016). It has to be underlined that nowhere else in Poland products of Cenozoic volcanism are so widespread and so well exposed and likewise, there is no other area where the legacy of three different volcanic epochs would be present.

Thus, approximately one hundred years of geoscientific research helped to recognize the region as one of the key areas to understand regional geological history and provided solid background for popularization of geoheritage and building of geotourist product. Although this potential was realized at least since the late 1960s (Birkenmajer 1967; Grocholski and Jerzmański 1975), linkages between geoheritage and tourist use have begun to be explored only recently (Cedro et al. 2009; Różycka 2014; Migoń and Pijet-Migoń 2016; Muszer and Muszer 2017; Różycka and Migoń 2018).

\section{Geoheritage and Tourism-Historical Overview}

Within the broader region of the Sudetes, the area included in the Land of Extinct Volcanoes had never been a popular tourist 

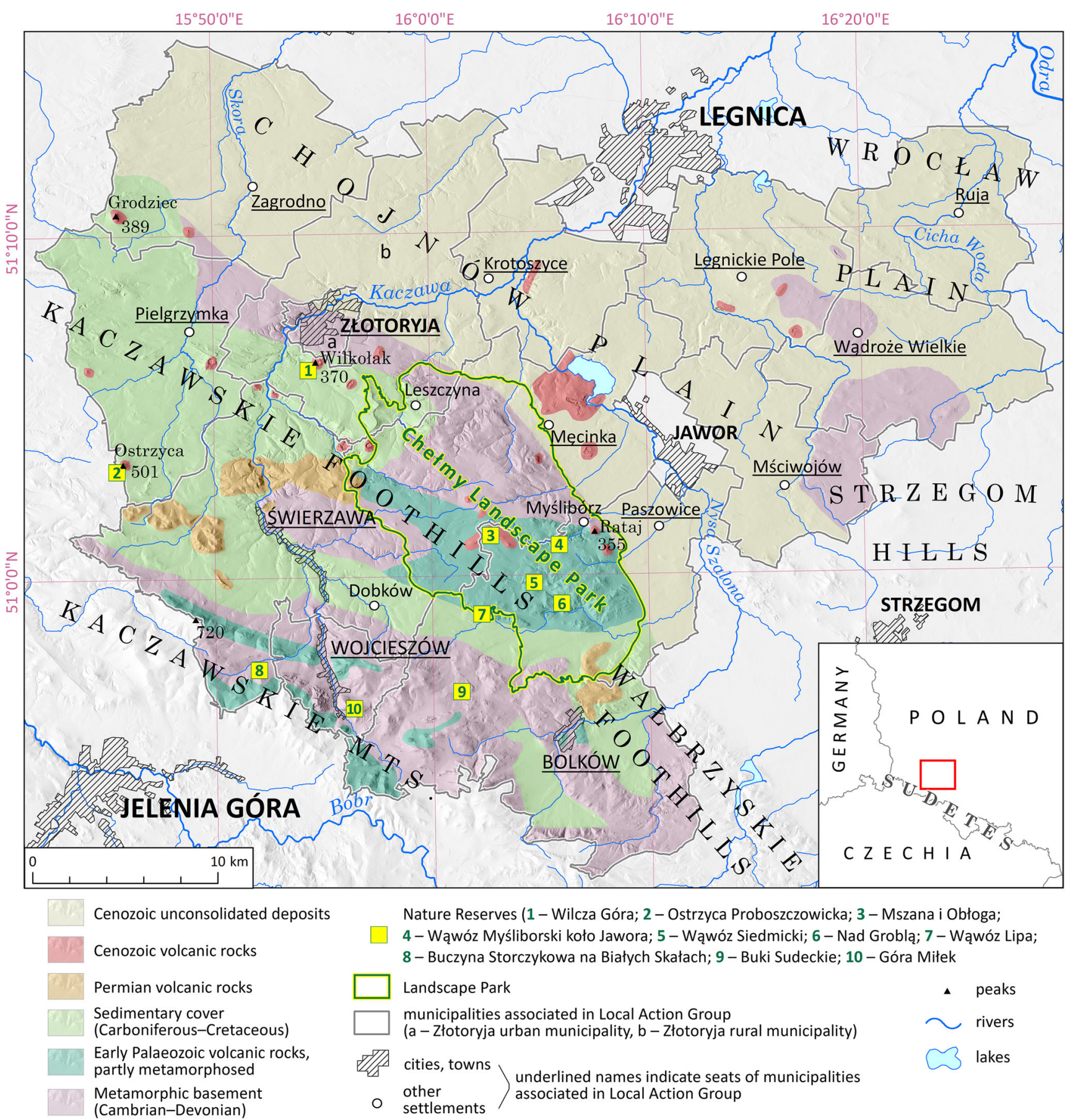

Fig. 1 The area referred to as the Land of Extinct Volcanoes, shown on a background of simplified geology and relief

destination, being overshadowed by the nearby Karkonosze Mountains - the highest and most spectacular mountain terrain within the Sudetes (Potocki 2004). Nevertheless, the regular solitary basaltic cone of Ostrzyca $(501 \mathrm{~m})$ was a regional landmark, nicknamed as "Silesian Fuji-yama." Basic tourist provisions were implemented in the first half of the twentieth century and included a flight of stone steps leading to the summit, safety handrails on the summit viewpoint, and a tourist lodge offering accommodation and meals at the footslope (Staffa et al. 2002).
Since 1926, the hill was protected as a nature monument, for the presence of both botanical values and basaltic blockfields. However, despite the natural values, visitations were not as frequent as on another volcanic hill nearby-Grodziec - where partly restored ruins of a medieval castle were the main attractor.

The first attempts to link tourism with geoheritage, focused on the volcanic past as the most unique and probably most understandable part of the Earth history, date back to the 1980s. An 85km-long hiking trail named as "The Trail of Extinct Volcanoes" 
was marked, connecting about ten localities of Cenozoic basalts and Permian rhyolites. In 1992, the eastern part of the Kaczawskie Foothills region became a formally protected area of a status of Landscape Park, named "Chełmy" (the name meaning gently domed hills), whereas an important development was the opening of an educational center in Myślibórz (Wiśniewski and Horoszko 2013a) (Fig. 2). However, education was mostly towards biology and ecology rather than geosciences, although some educational trails built at that time emphasized rock record, geomorphic change, and mining history and a geological guidebook and map for tourists were published (Grocholski and Wiśniewski 1995). A few more strictly protected areas (nature reserves) were established (Figs. 1 and 2), but their geoheritage values were apparently considered secondary in comparison with botanical values.

In the same period of the 1990s, when political change in Poland fostered various bottom-up initiatives, a Polish Brotherhood of Gold Diggers was established in the town of Złotoryja, aiming to recreate regional traditions of gold prospecting that was widely carried out in medieval times (Rogowski 2016). Since 1994, National Championships in gold panning have been organized in Złotoryja, which soon became very popular and widely covered by the media (Fig. 2). In 2000 and 2011, the World Championships in Gold Panning were held in Złotoryja. In more general terms, gold prospecting traditions have become one of the identifiers of the region on the tourism market and the basis for niche adventure tourism (Maciejakowie 1999; Maciejak and Maciejak 2007). Exploitation of Earth heritage in the context of tourism was also at the core of another local initiative, to revive traditions of iron smelting and lime burning. An old mining and smelting center in Leszczyna was partly revitalized, including renovation of two historic lime kilns and tracing of an educational trail focused on mineral resources and mining heritage (Wiśniewski and Horoszko 2013b). Since 2001, a tourist event known as Dymarki Kaczawskie (Kaczawa Bloomery) has been organized (Rogowski 2014). All these activities certainly contributed to the better recognition of the region and the potential of regional geoheritage to underpin tourist development, but they were largely isolated and lacking one overarching umbrella. Proper geotourism and geoeducation were yet to arrive.

\section{Branding "Land of Extinct Volcanoes" and Building Geotourist Product}

\section{Involving Local Communities_-“Kaczawa Partnership" Local Activity Group}

Since the accession of Poland into the European Union in 2004, many economic operators and associations were entitled to apply for and to use various European funds to support regional development (Furmankiewicz and Foryś 2006), among them a newly created (2005) Local Action Group

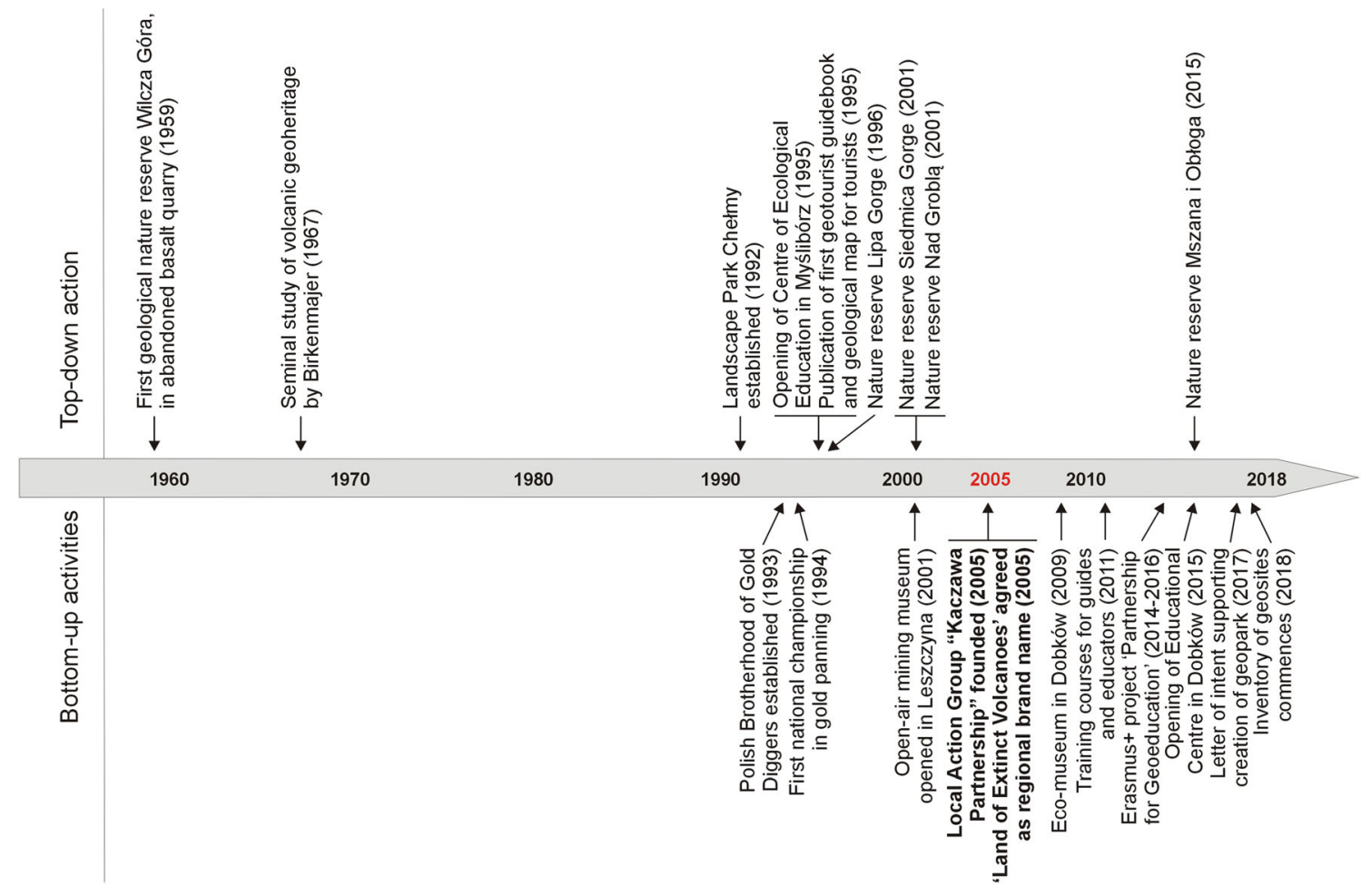

Fig. 2 Timeline of pro-geoheritage developments in the Land of Extinct Volcanoes 
"Kaczawa Partnership" (further referred to as LAG) (Fig. 2). Importantly, in terms of geography, it included not only municipalities (communes) from the Kaczawskie Mountains and the adjacent upland but also several of those located in the lowland terrain to the north-east of the Sudetes. However, even in the lowland part of the region, a dozen or so localities with exposures of volcanic rocks, mainly Cenozoic basalts, are present. Among the main goals of LAG was to promote tourism development on the basis of local resources, with the focus on unique characteristics, not present in other, more popular parts of the Sudetes. This view converged with an increasing scientific understanding, until then largely restricted to academic publications, that ancient volcanism is a distinctive element of geological history, not present anywhere else with such diversity and clarity of expression in the physical landscape. Therefore, the phrase "Land of Extinct Volcanoes" was selected as an official brand name for territorial marketing and the foundation to build and expand the regional tourist product, including various tourist products more or less directly related to geoheritage (Rogowski 2016). Since then, the name is consistently used in promotional and information materials, on roadside signposts and billboards. Simplified outlines of volcanic hills were placed on covers of books and brochures, calendars, or even school notebooks (Pijet-Migoń 2016).

LAG supported geoheritage-related mass events, both those with an established tradition (Gold Panning, Bloomeries) and the new ones such as the Cave Exploration Championships in Wojcieszów (competition of cave explorers and mountaineers in exploration and climbing techniques) or the Run of Extinct Volcanoes (cross-country run across highly difficult terrain, including volcanic hills). In parallel, support was offered to less publicized events, of more local character, related to vanishing agricultural and handicraft traditions. Although the latter are not directly related to geoheritage, they were used as opportunities to promote geotourism and geoeducation by means of performances, workshops, and contests.

Since its establishment, LAG has been strongly focused on regional education, mainly in the field of natural heritage. This is offered to both tourists and local population at all ages. For instance, schoolchildren education could have been enhanced by publication of various booklets about volcanoes and oneday field trips to the key volcanic geosites in the region. Adults involved in tourism business (hotel, B\&B and restaurant owners, travel agents, local administration) were invited to participate in a study tour to visit the most valuable natural sites, many not very well known before, so that these people can play the role of advisors to the tourists and direct them to geotourist attractions. In the framework of another project, a series of lectures and training courses was organized for local tour guides and other people willing to work as educators in the field of natural sciences.

\section{Following Good Practice}

The fascination with volcanoes has roots in the ancient times, whereas the early evidence of touristic visits to volcanoes (diaries and travelogues, chapters in books, paintings etc.) dates back to the times of the Grand Tour in the seventeenth-eighteenth century (Erfurt 2018). Nowadays, many volcanic destinations are easily accessible for tourists and some places are developing their tourist products based on the volcanic phenomena. Although active volcanism and related geothermal phenomena provide the most thrilling experience, dormant and extinct volcanoes can also be highly popular. To address the demand and to engage visitors, various interpretation approaches and techniques are implemented, being the key ingredient of "volcano tourism."

Volcanism as the main or secondary geological theme is exposed in many European geoparks, as well as outside Europe. Two among the founders of the European Geopark Network have outstanding volcanic heritage: Lesvos Petrified Forest in Greece and Vulkaneifel in Germany. Ongoing volcanism is present in Katla Geopark (Iceland), Azores (Portugal), and El Hierro (Spain). A few others UNESCO Global Geoparks, located in Central Europe, promote Cenozoic volcanic features as the main assets of their territories, such as the Bohemian Paradise (Czechia), BakonyBalaton (Hungary), and Novohrad/Nógrád (Slovakia, Hungary). This kind of geoheritage, with basaltic conical and tabular hills marking the location of the now eroded volcanoes, exposed columnar jointing of lava, and pyroclastic deposits, can be directly compared with the one present in the Land of Extinct Volcanoes. Consequently, interpretation activities developed in these areas might be followed, after adaptation to local conditions and context.

Therefore, it was realized that sharing experience and learning about good practice is important, especially at early stages of geoheritage-related activities, and to that end, a study tour to the transboundary Czech/German Bavarian-Bohemian Geopark was organized, as in terms of geology and landscape history, both regions have several similarities (Peterek et al. 2018). In 2014-2016, LAG benefited from the Erasmus Plus program and implemented the "Partnership for Geoeducation" project, in cooperation with three non-governmental organizations from other European countries involved in the promotion of local geoheritage for tourism and education: Adrimag (Portugal), Haskolafelag Sudurlands (Iceland), and Lag Papuk-Krndija (Croatia). Their long-term activities led to the establishment of geoparks which are now members of UNESCO Global Geoparks network, Arouca (in 2007), Katla (in 2011), and Papuk (in 2007), respectively. Both academic advisors to LAG and representatives of local communities participated in exchange visits. Among the achievements of the project was a handbook of outdoor geoeducation, which included scenarios of workshops and classes focused 
on various themes from the realm of geology and physical geography.

LAG closely cooperates with the academia, seeking advice from scientists from different fields, active in the Land of Extinct Volcanoes. To this end, a Scientific Advisory Board was established which includes geologists, geomorphologists, geographers, landscape architects, and tourism specialists. Representatives of LAG participate in national conferences aimed at exchanging good practices from various areas within Poland, where geoheritage is considered an important regional asset and foundation of a tourist product.

\section{Development of Tourist Infrastructure}

For many years, the development of tourist infrastructure, especially tracing and signposting of hiking trails, was an example of top-down approach, coordinated and executed by a few national organizations, with a very minor role of local partners. This has changed in the last two decades or so and many new infrastructural projects have been initiated and implemented by local communities. They include new hiking trails, especially aimed at connecting sites of interest with villages lacking such connections in the past, expansion of biking routes with necessary facilities in resting areas, building of educational paths, erection of information panels, development of picnic places and rest areas, and building of viewing towers (Fig. 3a). The latter play an important part in generally subdued, forested landscapes, both being new attractions for tourists and increasing opportunities to interpret the landscape and its history (Migoń and Pijet-Migoń 2017). Clearly, these developments have a wider purpose, to serve tourism in general and to make the region attractive to visitors with different backgrounds and expectations, not necessarily geoheritageoriented. However, they are crucial for geotourism too, facilitating visitations to localities with evident geoheritage component, not easily accessible before. The opening of more potential geosites may be particularly important for the socalled interested visitors (Dowling 2011), as recently discussed in the context of the Land of Extinct Volcanoes by Różycka and Migoń (2018). But there are also examples of action clearly directed towards geosite conservation. Several disused quarries, significant as sites of geological interest, have been recently cleared of invasive vegetation, bringing back features of columnar jointing and other structures into spotlight (Fig. 3b).

The biggest and the most ambitious infrastructural project executed in the last few years, funded from external European and domestic sources allocated to regional development, was building of an educational center in the village of Dobków, focused on geoheritage, particularly volcanism and Earth dynamics (Fig. 3c). The official name of the center may be translated as the "Sudetic Educational Farmstead" which emphasizes the location in an old Franconian-style farmstead, typical for the region, recently abandoned and then converted to serve educational purposes (Pijet-Migoń and Migoń 2014). Renovation of the building complex commenced in 2012 and the center was opened in August 2015. A significant part of work, especially at the early stage, was carried out by local volunteers, further indicating community involvement. The educational center allows visitors to undertake various activities. Part of it is an interactive exhibition which illustrates both general issues of Earth structure, volcanism, seismicity, and fluvial processes in the context of proper land use in river valleys as well as provides details of selected geosites in the region. The center has laboratory facilities, classrooms, and a conference room. Local rocks can be seen explained on the annotated wall of the former cowshed (Fig. 3d), whereas further exhibits to show principles of gold panning and wind erosion are located in the courtyard. Special workshop offers an opportunity to learn about the process of stone dressing and mineral polishing, especially agates, which are "the gems of the region." Thanks to the center, opening five full-time jobs were created, including four guides and educators.

\section{Educational Activities-Geoeducation Through Experience}

Since the opening, the educational center in Dobków has been very popular. Nearly 14,000 visitors were recorded in 2017 (the number of visitors in 2016 was only slightly less) and in terms of group visits, the center is currently working at nearly full capacity (pers. comm. from staff of the center). It may be visited individually (for free) or with the company of a guide (for a fee), and a range of thematic courses and school lessons can be booked for groups. All organized activities are oriented towards active learning and self-discovery of natural processes and relationships in nature, including those between geology and other spheres. The most frequented laboratory classes are "Adventures of Junior Scientists," workshops focused on properties of water, minerals, and fossils. Each of these is illustrated using specimens and evidence from the region, the former having been donated by the Geological Museum of the University of Wrocław. Other activities, such as geological trips, search for agates, gold panning, or renewable energy workshops, are held outdoors. During some of them, participants are taken to ancient volcanic localities, e.g., to an abandoned quarry of Permian trachybasalt at Łomy, where agates may be found in widespread talus below former quarry walls. The offer of geoheritage-oriented activities is supplemented by classes more focused on biology, ecology, and rural traditions.

\section{Other Activities Related to Regional Cultural Heritage}

In accordance with the holistic view of geoheritage promotion (Hose 2012), especially within geoparks, and realization that 
Fig. 3 Examples of recent developments in geoheritage promotion in the Land of Extinct Volcanoes. a Building of a viewing tower next to the village of Mściwojów, in the lowland part of the region, allows to interpret the landscape. b Rataj volcanic geosite was recently cleared of invasive vegetation and two interpretation panels were erected, one for more interested geotourists and one for casual visitors. c New interpretation center in Dobków, opened in 2015 in a renovated old farmstead. Gold panning facility in the courtyard. $\mathbf{d}$ Explanation of local rocks used to construct farm buildings, Dobków
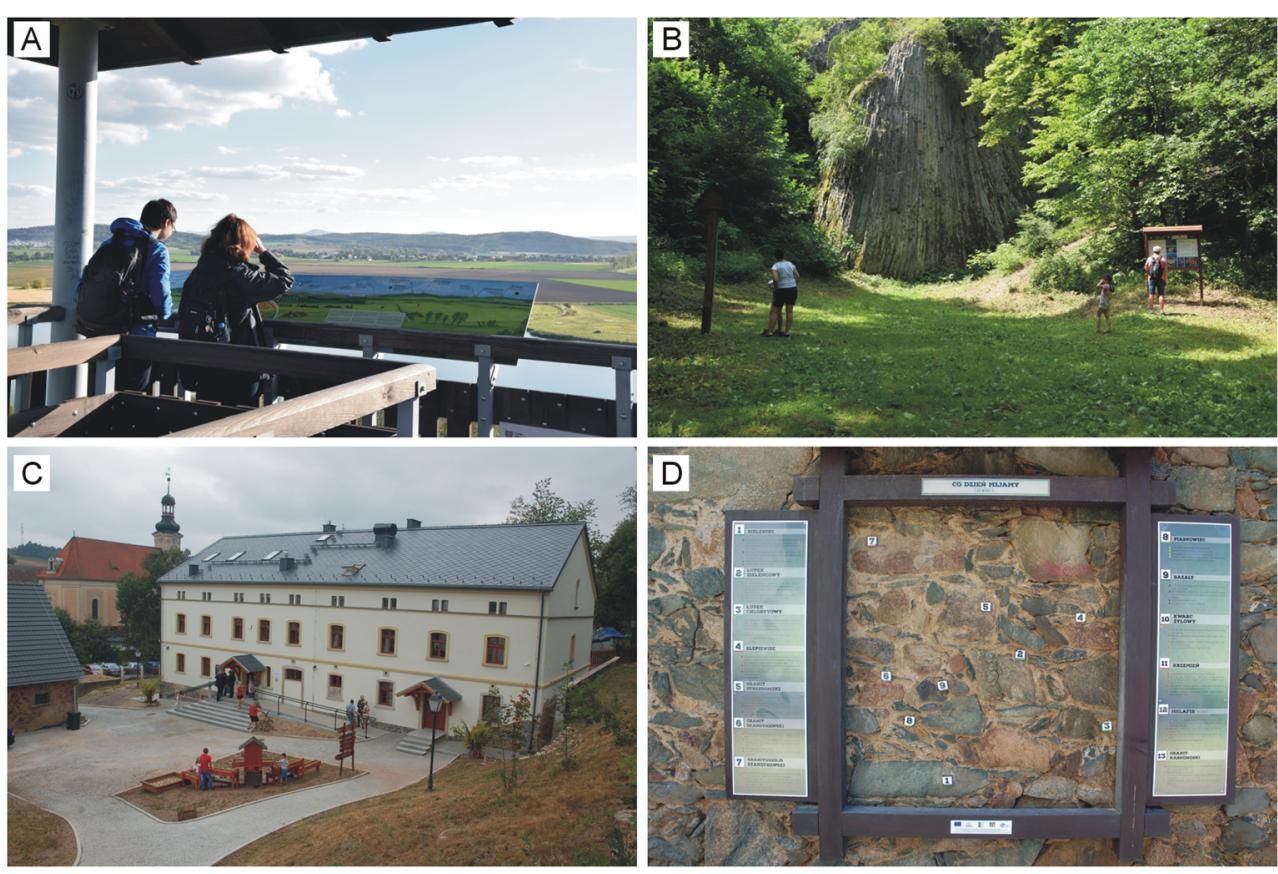

the proportion of narrowly oriented geotourists (i.e., seeking only experience related to geoheritage) is likely to be very small, regional education is not confined to geology per se, but involves a wider range of activities and themes, related to the traditional style of life and occupations of local inhabitants. They are organized in various places within the Land of Extinct Volcanoes and led by people involved in such activities on a daily basis. Thus, the offer includes pottery making and paper handmaking workshops, lessons of weaving, organic cosmetic manufacturing, and cooking based on common plants and herbs. Presentations of beekeeping proved very popular, as well as wool making workshops in an ecological farm specialized in sheep breeding. The educational offer is constantly being enlarged.

An important role played by the educational center consists in coordinating the schedule of proposed workshops so that they do not overlap and interested visitors, especially during weekends, can take part in various activities. The attendance is fee-based and hence, the leaders and guides receive supplementary income, whereas a proportion of benefits is spent on joint promotional campaigns for the future. Coordinated promotion helps to achieve the scale effect and facilitates building of a consistent image of the region and its tourist product. It is realized that a diverse offer enhances the attractiveness of the area, may encourage visitors to extend the stay, and provides good alternative during poor weather conditions.

In addition to ongoing emphasis on geological heritage, strengthening regional identity is also accomplished through revitalization of rural areas, with the aim to sustain their traditional appearance and architecture, harmoniously blended with the surrounding physical landscape. Here, the target group is the local population which, in effect of post-World War II political changes in this part of Europe, does not have family roots in the region. Several small projects have been executed, focused on restoration of front and backyard gardens, return to traditional fruit trees in orchards, vegetable, and herb planting. Although none of these actions is directly related to geoheritage, it is assumed that esthetically pleasant rural areas will be more attractive to tourists who then decide to stay in these villages rather than in more developed, but also more crowded, tourist centers outside the Land of Extinct Volcanoes.

\section{Plans for the Future-Towards a Geopark}

The long-term goal for the LAG is to formally establish a geopark in the Land of Extinct Volcanoes which might apply for the status of a UNESCO Global Geopark. It is believed that the primary criteria established for Global Geoparks such as the presence of outstanding geoheritage and local community involvement are or may be fulfilled in not too distant future. After several years of presenting the idea to potential stakeholders, a meeting of all local leaders (municipality mayors) took place in October 2017, ending with signing an official letter of intent which paves the way to the geopark. One small project in this context, to be implemented in the near future, is to develop a regional library collection and tourist information point at the educational center in Dobków, which would become a hub for tourists visiting the region. The most recent initiative is a project aimed at the inventory of geosites within the Land of Extinct Volcanoes and the selection of key localities, to 
which efforts to make them available to the general public can be directed. Although the project itself will be carried out by scientists, partnership with the local people is considered very important to ensure success of this endeavor, especially regarding the state of preservation and accessibility of the sites. The first round of consultations with the local communities proved very successful, resulting in various additional proposals and comments. It showed that the brand name "Land of Extinct Volcanoes" is firmly embedded in the collective mind of local stakeholders and the idea of working towards a UNESCO Global Geopark enjoys sufficient support to make further action worthwhile.

Since geoparks are required to have clear territorial boundaries and legal status, these issues are currently under discussion among the local stakeholders. At the moment, it is envisaged that the 14 municipalities involved in the Local Activity Group will jointly constitute the geopark and hence, its boundaries will be identical with the extent of the municipalities (Fig. 1). Regarding management, two options are currently under consideration. In the first one, the future geopark will be administrated by the existing local association "Stowarzyszenie Kaczawskie" which is based on individual membership. Alternatively, a new legal body will be created - the Association of Municipalities. All local governments involved will become the members of the new Association.

\section{Concluding Remarks}

Although officially the Land of Extinct Volcanoes is not a geopark, even at the national level, examination of recent achievements and state-of-the-art of geoheritage promotion shows that the regions closely adopt the core values of the UNESCO Global Geopark network, defined as the presence of geoheritage of considerable significance, involvement of local communities in geoheritage matters, and the strategy of sustainable development based on local resources (Brilha 2017). In addition, emphasis on geoheritage is twinned with evident attention paid to other aspects of local heritage, such as traditional rural architecture, traditional occupations, and handicraft. A comparable holistic approach to heritage can be found in many other geoparks, especially in Europe (Zouros 2008). Thus, the example of Land of Extinct Volcanoes demonstrates that good practices are not necessarily tied with formal recognition and may be successfully implemented without the latter. Actually, this is in accordance with one of the general principles of setting up a geopark that an aspiring area should be a de facto geopark, i.e., good practices necessary to fulfill the goals of the geopark program should already be adopted. The current activities undertaken in the Land of Extinct Volcanoes will appropriately contribute to the ultimate application to the UNESCO Global Geopark network.

The following characteristics make the Land of Extinct Volcanoes distinctive, at least among other areas in Poland where the idea of a geopark is contemplated (Alexandrowicz and Miśkiewicz 2016). First, it is very good communication between academia and local leaders, so that transfer of knowledge can be successfully accomplished. The setting up of a scientific advisory board, organization of training courses, and publications are the key activities in this respect. Second, there is strong local leadership, combined with broader understanding of geoheritage-related issues achieved during several study tours and educational programs aimed at local stakeholders. Third, it is realized that the success depends on acceptance and identification with the goals. Positive lobbying for geoheritage promotion and future geopark, carried out since nearly a decade ago, has resulted in general support to the idea, as exemplified by the letter of intent signed by representatives of all 14 local communities. Fourth, a clear longterm strategy is followed, with various milestones set and achieved on the way. The short- and medium-term goals are realistic and bring immediate benefits to the local communities, increasing support to the geopark as the ultimate goal.

However, problems still remain and if not resolved, they may jeopardize the future of the Land of Extinct Volcanoes as a geo-destination. Any long-term strategy has to address the issue of geosite management and define responsibilities. At the moment, the sites are in the hands of various stakeholders and their goals may differ from the interest of geoheritage conservation and promotion. For example, the establishment of several nature reserves in the region provided legal framework for protection, but at the same time access to several geologically and geomorphologically valuable localities has become restricted. It has been shown that interests of geoheritage and biological conservation may be reconciled (Świerkosz et al. 2017), but it requires mutual understanding and agreement on priorities. Likewise, some geosites are on private grounds and their future, including access, depends on the good will of the landowners. Another potential source of tension is the non-uniform distribution of geoheritage values within the Land of Extinct Volcanoes, with the upland part in the west being much more endowed by nature than the lowland in the east, which may result in disproportionate benefits to participating municipalities. Therefore, a good strategy to enhance attractiveness of the geotouristic product in the lowland has to be developed. A more explicit emphasis of linkages between geo-resources and rich historical heritage of the lowland part is an option to follow, whereas some natural rock outcrops and disused quarries, if cleared of vegetation and properly signposted, have a potential to become local highlights. A challenge for the future is the fate of operating quarries after operations are finished. Some of them, such as 
the big limestone quarry in Wojcieszów (Muszer and Muszer 2017) or the basalt quarry at Wilkołak (Maciejak and Gorzkowski 2010), provide excellent insights into the geological past and may be developed into first-class open-air geological and mining museums, but a vision how to proceed should be developed now, to avoid implementation of rehabilitation means inconsistent with geoconservation (e.g., complete afforestation or re-use as dumping site).

In summary, the case of Land of Extinct Volcanoes illustrates the links between science and practice and how they can be developed. In the context of geoparks and geoheritage popularization, academic research provides the necessary background for further activities, but these - to be successful and sustainable in the long term - have to be implemented by local communities themselves, perhaps slowly rather than rapidly, ensuring and monitoring support to the general idea. The advisory role of scientists is important but will not replace action at the local level.

Acknowledgments The authors acknowledge the most fruitful cooperation with the members of Local Activity Group "Kaczawa Partnership," enjoyed since a decade ago, particularly Ewelina and Krzysztof Rozpędowscy and Julia Jankowska. Joint field visits with Krzysztof Maciejak are also gratefully acknowledged. Kacper Jancewicz is thanked for elaborating Fig. 1. Very helpful comments from two journal reviewers are gratefully acknowledged.

Open Access This article is distributed under the terms of the Creative Commons Attribution 4.0 International License (http:// creativecommons.org/licenses/by/4.0/), which permits unrestricted use, distribution, and reproduction in any medium, provided you give appropriate credit to the original author(s) and the source, provide a link to the Creative Commons license, and indicate if changes were made.

\section{References}

Aleksandrowski P, Mazur S (2002) Collage tectonics in the northeasternmost part of the Variscan belt: the Sudetes, Bohemian Massif. In: Winchester JA, Pharaoh TC, Verniers J (eds) Palaeozoic amalgamation of Central Europe, vol 201. Geol Soc Spec Publ, London, pp 237-277

Alexandrowicz Z, Miśkiewicz K (2016) Geopark - od idei do realizacji, ze szczególnym uwzględnieniem Polski (Engl. summ. Geopark from the concept to implementation, with special reference to Poland). Chrońmy Przyr Ojcz 72(4):243-253

Awdankiewicz M (2006) Fractional crystallization, mafic replenishment and assimilation in crustal magma chambers: geochemical constraints from the Permian post-collisional intermediate-composition volcanic suite of the North-Sudetic Basin (SW Poland). Geol Sudet 38:39-61

Badura J, Pécskay Z, Koszowska E, Wolska A, Zuchiewicz W, Przybylski B (2005) New age and petrological constraints on Lower Silesian basaltoids, SW Poland. Acta Geodyn Geomater 3(139):7-15

Baranowski Z, Haydukiewicz A, Kryza R, Lorenc S, Muszyński A, Solecki A, Urbanek Z (1990) Outline of the geology of the Góry Kaczawskie (Sudetes, Poland). N Jhrb Geol Paläont Abh 179:223257
Birkenmajer K (1967) Bazalty dolnośląskie jako zabytki przyrody nieożywionej (Engl. summ. Lower Silesian basalts as monuments of inanimate nature). Ochr Przyr 32:225-276

Birkenmajer K, Pécskay Z, Grabowski J, Lorenc MW, Zagożdżon P (2007) Radiometric dating of the tertiary volcanics in Lower Silesia, Poland. V. K-Ar and palaeomagnetic data from Late Oligocene to Early Miocene basaltic rocks of the North-Sudetic depression. Ann Soc Geol Pol 77:1-16

Brilha J (2017) Geoheritage and Geoparks. In: Reynard E, Brilha J (eds) Geoheritage: assessment, protection, and management. Elsevier, Amsterdam, pp 323-335

Cedro B, Mianowicz K, Zawadzki D (2009) Ocena walorów geoturystycznych stanowisk pochodzenia wulkanicznego Gór i Pogórza Kaczawskiego (Evaluation of geotourist values of volcanic sites in the Góry and Pogórze Kaczawskie). In: Dutkowski M (ed) Problemy turystyki i rekreacji 2. Oficyna In Plus, Szczecin, pp 2535 (in Polish)

Chrząstek A, Wojewoda J (2011) Mezozoik południowo-zachodniej Polski (synklinorium północnosudeckie) (Engl. summ. Mesozoic of South-Western Poland (The North Sudetic Synclinorium)). In: Żelażniewicz A, Wojewoda J, Cieżkowski W (eds) Mezozoik i kenozoik Dolnego Śląska. WIND, Wrocław, pp 1-10

Dowling RK (2011) Geotourism's global growth. Geoheritage 3(1):1-13

Erfurt P (2018) Geotourism development and management in volcanic regions. In: Dowling R, Newsome D (eds) Handbook of Geotourism. Edward Elgar, Cheltenham, pp 152-167

Furmankiewicz M, Foryś M (2006) Partnerstwa terytorialne na rzecz rozwoju obszarów wiejskich w polskiej części Sudetów - historia powstania i pierwsze efekty działan (Territorial partnerships for the development of rural areas in the Polish part of the Sudetes - history of origin and first effects of activity). In: Furmankiewicz M, Jadczyk J (eds) Problemy współpracy na rzecz ekorozwoju Sudetów. Muzeum Przyrodnicze w Jeleniej Górze, Jelenia Góra, pp 109128 (in Polish)

Grocholski A, Jerzmański J (1975) Zabytki paleowulkanizmu na Dolnym Śląsku w świetle ochrony przyrody (Engl. summ. Paleovolcanic occurrence in the Lower Silesia in the light of nature protection). Ochr Przyr 40:291-340

Grocholski A, Wiśniewski E (1995) Przewodnik geologiczny po Parku Krajobrazowym Chełmy na Pogórzu Kaczawskim (Geological guidebook of the Chełmy Landscape Park in the Pogórze Kaczawskie). Państwowy Instytut Geologiczny, Wrocław (in Polish)

Grodzicki A (1972) Petrografia i mineralogia piasków złotonośnych Dolnego Ślaska (Engl. summ. On the petrography and mineralogy of the goldbearing sands of Lower Silesia). Geol Sudet 6:233-291

Hose TA (2012) 3G's for modern geotourism. Geoheritage 4:7-24

Kasprzak M, Traczyk A (2009) Skałki keratofirowe okolic Kaczorowa w Górach Kaczawskich (Keratophyre tors in the vicinity of Kaczorów in the Kaczawskie Mountains). Przyr Sudetów 12:123-134 (in Polish)

Kryza R, Muszyński A (1992) Pre-Variscan volcanic-sedimentary succession of the central southern Góry Kaczawskie, SW Poland: outline geology. Ann Soc Geol Pol 62:117-140

Maciejak K, Gorzkowski R (2010) Rezerwat przyrody Wilcza Góra i jego rola w edukacji przyrodniczej i regionalnej (Engl. summ. The Wilcza Góra nature reserve and its role in environmental and regional education). In: Gorzkowski R (ed) Wilkołak (Wilcza Góra) koło Złotoryi. Geologia - przyroda - historia. Towarzystwo Miłośników Ziemi Złotoryjskiej, Złotoryja, pp 135-165

Maciejak K, Maciejak M (2007) Złoto. ABC Poszukiwacza (Gold. ABC of a Prospector). Goldcentrum, Złotoryja (in Polish)

Maciejakowie KK (1999) Złoto. Vademecum Poszukiwacza (Gold. Vademecum of a Prospector). Atut - Polskie Bractwo Kopaczy Złota, Złotoryja (in Polish) 
Migoń P, Pijet-Migoń E (2016) Overlooked geomorphological component of volcanic geoheritage - diversity and perspectives for tourism industry, Pogórze Kaczawskie region. SW Poland. Geoheritage 8: 333-350

Migoń P, Pijet-Migoń E (2017) Viewpoint geosites - values, conservation and management issues. Proc Geol Assoc 128:511-522

Migoń P, Maciejak K, Zygmunt M (2002) Peryglacjalna rzeźba wzgórz bazaltowych Pogórza Kaczawskiego (Sudety Zachodnie) i jej znaczenie dla paleogeografii plejstocenu (Engl. summ. Periglacial morphology of basalt hills in the Kaczawa Upland (Western Sudetes) and its significance for Pleistocene palaeogeography). Prz Geogr 74:491-508

Muszer J, Muszer A (2017) Evaluation of the geotouristic attractions from the Wojcieszów area. Geotourism 1-2(48-49):31-46

Peterek A, Rund M, Schnabel M (2018) Der grenzüberschreitenden Bayerisch-Böhmische Geopark. Schrift Dt Gesell Geowiss 93:8795

Pijet-Migoń E (2016) Geoturystyka-nowe możliwości wykorzystania dziedzictwa Ziemi w turystyce. Studium przypadku Krainy Wygasłych Wulkanów w Sudetach Zachodnich (Engl. summ. Geotourism - new opportunities to use geoheritage for tourism development. Case study of Land of Extinct Volcanoes in the West Sudetes). Ekon Probl Turystyki 1(33):301-312

Pijet-Migoń E, Migoń P (2014) Turystyka w kreatywnej wsi - studium przypadku wsi Dobków na Pogórzu Kaczawskim (Engl. summ. Tourism in a creative village - a case study of Dobków in the Kaczawskie Foothills). Rozpr Nauk AWF we Wrocławiu 46:129 139

Placek A (2011) Rzeźba strukturalna Sudetów w świetle wyników pomiarów wytrzymałości skał i analiz numerycznego modelu wysokości (Rock-controlled morphology of the Sudetes in the light of rock strength measurements and DEM analysis). Rozpr Nauk Inst Geogr Rozw Reg Uniw Wrocł 16:1-190 (in Polish)

Potocki J (2004) Rozwój zagospodarowania turystycznego Sudetów od połowy XIX wieku do II wojny światowej (Development of tourist infrastructure in the Sudetes since the mid-19th century until World War II). Plan, Jelenia Góra (in Polish)

Pulina M (1977) Zjawiska krasowe w Sudetach polskich (Engl. summ. Karst phenomena in the Polish Sudetes). Dok Geogr IGiPZ PAN 23(1977):1-118
Rogala W (2003) Pionowy układ jaskiń krasowych na górze Połom w Górach Kaczawskich. Prz Geol 51:238-242

Rogowski M (2014) Produkty geoturystyczne Sudetów jako unikatowa oferta regionu (Engl. summ. Geotourist products of the Sudetes Mountains as unique offers of the international region). Studia Periegetica 2(12):93-107

Rogowski M (2016) The potential of the Sudetes Mountains for the development of geotouristic products. Geotourism 3-4(46-47):59 80

Różycka M (2014) Atrakcyjność geoturystyczna okolic Wojcieszowa w Górach Kaczawskich (Engl. summ. Geotourism attractiveness of the area around the town of Wojcieszów, Kaczawskie Mts.). Prz Geol 62:514-520

Różycka M, Migoń P (2018) Customer-oriented evaluation of geoheritage - on the example of volcanic geosites in the West Sudetes, SW Poland. Geoheritage 10:23-37

Solecki A (1994) Tectonics of the North Sudetic Synclinorium. Acta Univ Wratisl 1618. Prace Geol-Min 45:1-59

Solecki A (2011) Rozwój strukturalny epiwaryscyjskiej pokrywy platformowej w obszarze synklinorium północnosudeckiego (Engl. summ. Structural development of the epi-Variscan cover in the North Sudetic Synclinorium area). In: Żelażniewicz A, Wojewoda J, Cieżkowski W (eds) Mezozoik i kenozoik Dolnego Śląska. WIND, Wrocław, pp 19-36

Staffa M, Mazurski KR, Pisarski G, Czerwiński J (2002) Słownik geografii turystycznej Sudetów, 7, Pogórze Kaczawskie (Dictionary of Tourism Geography of the Sudetes, 7, Pogórze Kaczawskie). I-Bis, Wrocław (in Polish)

Świerkosz K, Koźma J, Reczyńska K, Halama M (2017) Muskau Arch Geopark in Poland (Central Europe) - is it possible to integrate geoconservation and geoeducation into biodiversity conservation? Geoheritage 9:59-69

Wiśniewski E, Horoszko T (2013a) Park Krajobrazowy "Chełmy" (Chełmy Landscape Park). DZPK, Myślibórz (in Polish)

Wiśniewski E, Horoszko T (2013b) Śladami dawnego górnictwa. Przewodnik turystyczny po Leszczynie (On the Traces of Ancient Mining. Tourist Guidebook around Leszczyna). DZPK, Myślibórz (in Polish)

Zouros NC (2008) European Geoparks Network: transnational collaborations on Earth heritage protection, geotourism and local development. Geotourism 1(12):3-22 